University of Louisville

ThinkIR: The University of Louisville's Institutional Repository

Electronic Theses and Dissertations

$12-2006$

\title{
Syllable systems : four students' experiences in learning rhythm.
}

Tammy Renee Fust

University of Louisville

Follow this and additional works at: https://ir.library.louisville.edu/etd

\section{Recommended Citation}

Fust, Tammy Renee, "Syllable systems : four students' experiences in learning rhythm." (2006). Electronic Theses and Dissertations. Paper 473.

https://doi.org/10.18297/etd/473

This Master's Thesis is brought to you for free and open access by ThinkIR: The University of Louisville's Institutional Repository. It has been accepted for inclusion in Electronic Theses and Dissertations by an authorized administrator of ThinkIR: The University of Louisville's Institutional Repository. This title appears here courtesy of the author, who has retained all other copyrights. For more information, please contact thinkir@louisville.edu. 
SYLLABLE SYSTEMS:

FOUR STUDENTS' EXPERIENCES IN LEARNING RHYTHM

By

Tammy Renee Fust

B.M.E. University of Kentucky, 2001

A Thesis Submitted to the Faculty of the Graduate School of the University of Louisville

In Partial Fulfillment of the requirements

For the degree of

Master of Music Education

School of Music

University of Louisville

Louisville, Kentucky

December 2006 


\title{
SYLLABLE SYSTEMS: FOUR STUDENTS’ EXPERIENCES IN LEARNING RHYTHM
}

\author{
By \\ Tammy Renee Fust \\ B.M.E., University of Kentucky, 2001
}

A Thesis Approved on

December 6, 2006

By the following Thesis Committee:

Thesis Director 


\section{DEDICATION}

This thesis is dedicated in loving memory of my mother

Donna Lee Fust

without whom I would not be who I am today. 


\section{ACKNOWLEDGEMENTS}

There are several people I would like to thank for their persistent support during this process. I thank my thesis advisor Dr. Robert Amchin for his time and guidance on this project, as well as his positive attitude during the entire process. I would also like to thank those on my thesis committee, Dr. Greg Byrne for his help and encouragement, and Dr. Anne Marie de Zeeuw for her generous gift of time and attention to detail.

This project could not have been done without the kind help of Mr. Kevin Cox who invited me in to his classroom to gather data for my research. I would also like to thank my four subjects and their parents for being so flexible with busy schedules, as well as Lynda Redmon, the principal of the middle school in Oldham County, for allowing me to conduct research there as well as showing her enthusiasm for the project.

I owe a debt of gratitude to Mr. Brad Rodgers, my band director for many years, who inspired me to teach music and who continues to be one of the best at what he does. I thank my father, Chester Fust, for his warm encouragement, love, and support through my time at the University of Louisville. Without his help, I would have never made it this far. Lastly, I am grateful for my fiancé, Matthew Oerther, who constantly encouraged me, listened to me, and put up with me while I was working on this project and my degree. 


\section{ABSTRACT \\ SYLLABLE SYSTEMS: \\ FOUR STUDENT'S EXPERIENCES IN LEARNING RHYTHM \\ Tammy Fust}

December 6th, 2006

This qualitative study examines the effect of two different syllable counting systems on four sixth-grade band students. The goal of this study was to see the differences and similarities between rhythm learning and performance between these students in four related case studies. During a series of five lessons, students spent time with the researcher individually exploring rhythm reading and performing on their instrument.

Two of the students were taught to count rhythms with the "takadimi" rhythm syllable system as developed by Richard Hoffman, William Pelto, and John White. The other two students counted rhythms using the traditional "1-e-\&-a" system of counting most familiar to instrumental teachers in the United States. Subjects' experiences in counting rhythms using these systems were compared and contrasted to find what similarities or differences existed. Lessons with each student were also videotaped, and the lessons were transcribed to ascertain trends and differences between each teaching 
setting and rhythm system. This was also done to have a complete record of each teaching period. The researcher also kept a journal for reflection after each lesson in order to better understand and reflect on student learning. Data collected from the videotape transcripts reflected that students made mistakes that fell into six categories: (1) holding a note or rest too long, (2) playing a note or rest too short, (3) wrong syllable used, (4) unsteady pulse, (5) stops and hesitations due to rushing, and (6) incorrect rhythm. Analysis of this data resulted in identifying specific problems arising from the two rhythm methods used. Results showed that there were no apparent differences in achievement between the two approaches to learning rhythm. The students, regardless of method, generally made the same types of errors when counting and playing rhythms; they made fewer errors when they counted a rhythm before playing it rather than playing it first. The limitations of the study and suggestions for further studies are given. 


\section{TABLE OF CONTENTS}

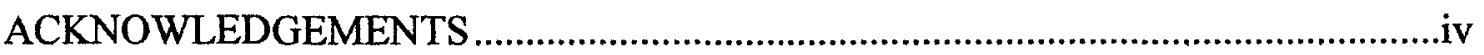

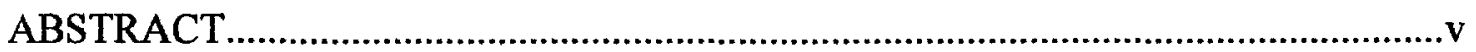

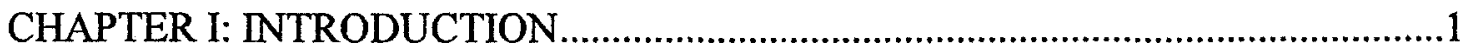

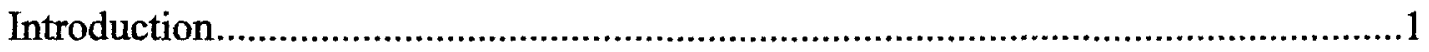

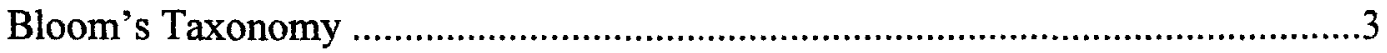

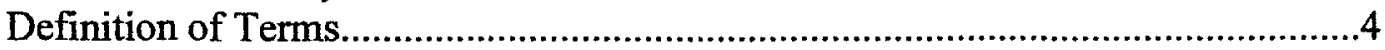

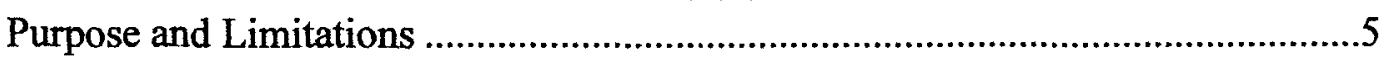

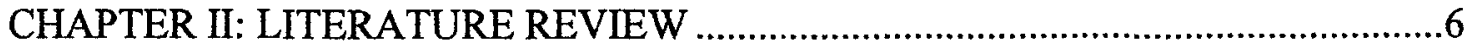

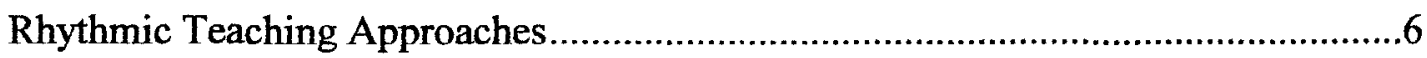

The French Time-Names System......................................................................

Adaptations to the French Time-Names System ………....................................

The Dalcroze Approach ....................................................................................10

The Orff Approach...........................................................................................10

The Kodály Approach..............................................................................................12

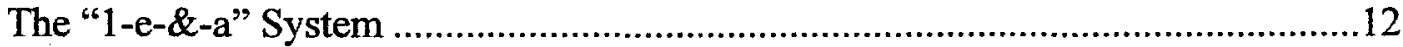

The McHose/Tibbs System.................................................................................13

The James O. Froseth System ..............................................................................14

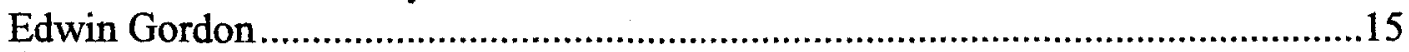

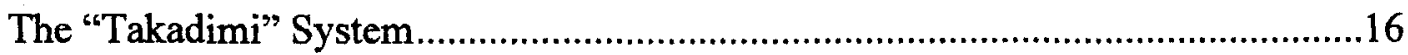

Comparisons and Systematic Analyses of Rhythmic Approaches .............................17

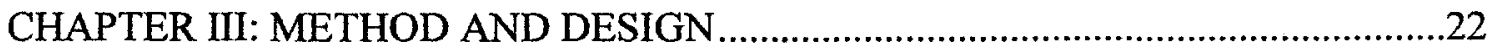

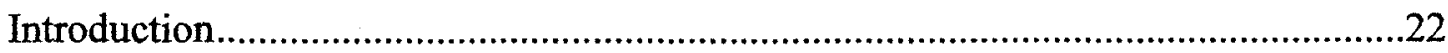

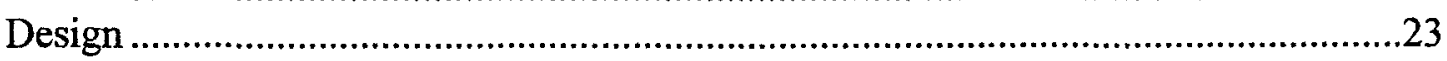

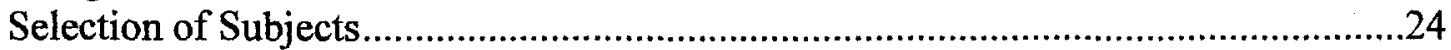

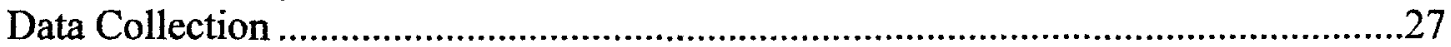

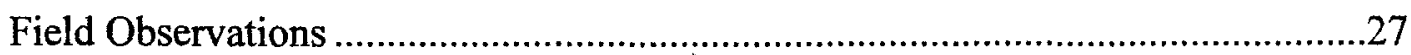

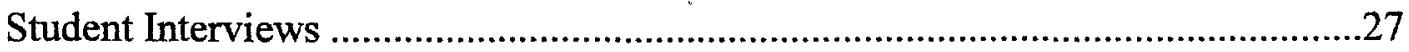

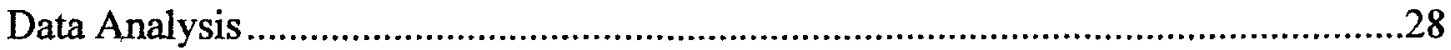

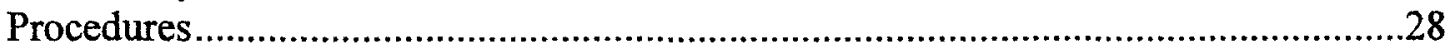

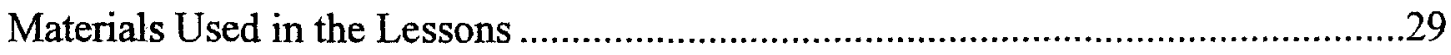


CHAPTER IV: RESULTS

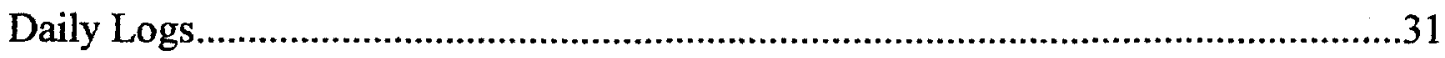

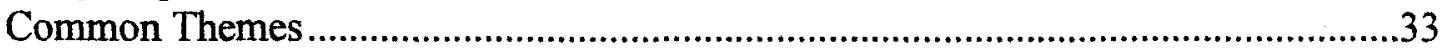

Unusual Observations and Comments ...................................................................35

Final Interview and Questions ............................................................................36

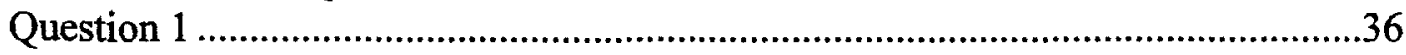

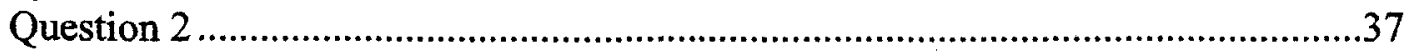

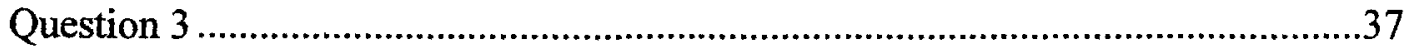

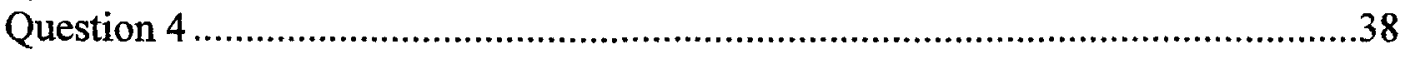

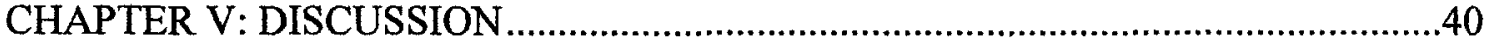

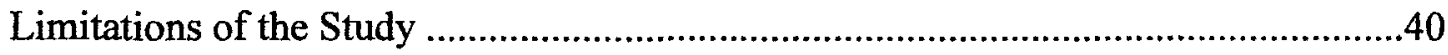

Areas for Further Consideration .............................................................................41

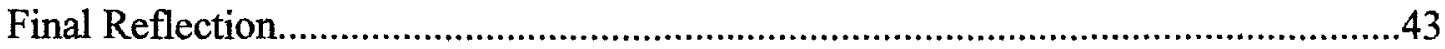

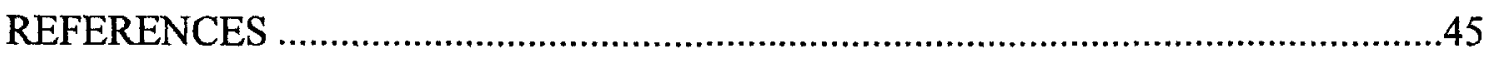

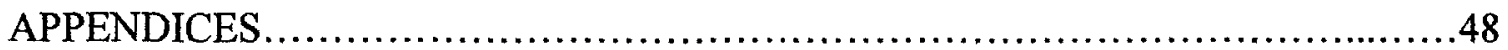

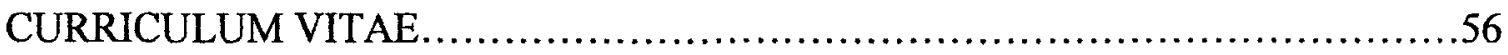




\section{CHAPTER I}

\section{INTRODUCTION}

Curriculum in instrumental music education extends beyond learning pieces for concert performances or for state contests. In addition to teaching repertoire, a quality music program presents the elements of music (harmony, melody, tempo, rhythm, dynamics, form, timbre), and meets standards such as those presented by MENC's (the National Organization for Music Education) "New Vision." In order to have a complete and competent program, each of these issues must be given appropriate attention and instruction by the teacher.

Ideally, quality music education curricula address state outcome requirements and utilize the National Standards for Arts Education put forth by MENC. Standard Five of the MENC standards (in the list of nine) includes that students should be able to read and notate music. ${ }^{2}$ Music teachers are therefore always striving to find better ways for their students to learn to read music more efficiently.

In the Commonwealth of Kentucky, the Core Content for Assessment is based upon the National Standards for the Arts. Specific guidelines are given about the Structures in the Arts, such as the elements of music. AH-06-1.1.1 from the Core Content for Assessment in Music for middle school students states that, "Students will

\footnotetext{
${ }^{1}$ Music Educators National Conference, The School Music Program: A New Vision. The K-12 National Standards, Pre-K standards, and what they mean to music educators (Reston, VA: Music Educators National Conference, 1994)

${ }^{2}$ Ibid.
} 
identify or describe the use of elements in a variety of music."1 Subsumed with this standard, elements of music are listed including specific vocabulary with which students should be familiar. Some of the vocabulary for the element of rhythm includes syncopation, time signature, and rhythmic durations (whole, half, quarter, eighth, sixteenth notes and rests, dotted half note and dotted quarter notes.) Therefore, students and their teachers are mandated to learn how to read music. A core component of this is the ability to effectively count and perform rhythms. Since children need to have individual attention in this process, it is appropriate and common to find music educators who favor one rhythm system over another. It is equally important to determine if alternative methods of rhythm reading is more suited for students. For this reason it is logical that music teachers find varied approaches to teaching rhythm in order to better reach each student.

Teaching rhythm to music students is central to any quality music program. The process of rhythmic training is found at all levels of instruction. The importance of this is demonstrated in time spent teaching rhythm in general music, choral, and instrumental classes.

There are many factors at work when students are asked to perform rhythm patterns. It is important to determine what can help students play a rhythm pattern accurately. In the most traditional setting, a student is presented with visual stimuli (musical notation) then is asked to read, react and perform the musical notes to a steady pulse, with appropriate division of the beat. Students may connect their reactions to the musical score using previous knowledge to transfer the music from visual stimuli to an

\footnotetext{
${ }^{1}$ Kentucky Department of Education, Core Content for Arts and Humanities Assessment, (August 2006)
} 
auditory musical event. Once the student processes how to play a rhythm, the brain sends messages to the body, which leads to accurate performances of a particular rhythmic structure. While deciphering the notation, students are also asked to perform instrumentally or vocally using appropriate technical facility. The struggles of coordinating accurate decoding of a written rhythm are compounded by the following skills: correct posture, embouchure setting, and having fingers in correct position on the instrument. When a student does not understand the notational system, or has had no experience with musical notation, it is not likely that the student will correctly perform the rhythm.

\section{Bloom's Taxonomy}

Perhaps the most helpful way in understanding how students learn rhythm is to look at it in reference to Bloom's taxonomy of cognitive development. This classification system developed by psychologist Benjamin Bloom has been used for decades to understand and enhance educational settings. Bloom's Taxonomy describes the process of learning by breaking it down into six cognitive areas. ${ }^{1}$ These subsets of learning move from simplest to most complex and are classified as knowledge, comprehension, application, analysis, synthesis, and evaluation. In order to perform a rhythm correctly, according to this theory, students must first have the knowledge of what notation is, and be able to identify a time signature, half-notes, eighth-notes, and other symbols before they can perform a selection of music. Many students could do this easily by using flashcards and recalling information. Then, they must comprehend how

\footnotetext{
${ }^{1}$ Benjamin Bloom, Taxonomy of Educational Objectives: the Classification of Educational Goals (New York: Longman, 1984), 8-27.
} 
many beats each note is held, as well as where the beats are in the measure, and be able to explain that to another student. This shows comprehension of the meaning of notational symbols. Students must then apply that knowledge to actual measures of rhythm in music and be able to identify those symbols in the music and comprehend what they mean within the context. Analysis is used often in reading rhythms because many times students must take music apart beat by beat in order to discern how it is counted and played. Synthesis happens when the parts are put back together and the measure or phrase of rhythm is performed correctly. Evaluation, the final stage of Bloom's taxonomy, helps students go beyond basic reading skills. The evaluation of their own and others' rhythm performances will only enhance students' learning.

\section{Definition of Terms}

The key terms and issues in understanding musical skill and rhythmic accuracy require a basic understanding of musical performance. The following lists the three key elements needed to understand the current study.

Perception: how a student first interprets a written rhythm by means of cognition.

Rhythm: a pattern of durations grouped into a musical unit.

Syllable System: a way of counting rhythms verbally using mnemonic sounds or words in order to measure out the space between notes. Such systems are often implemented in order to aid musicians in performing rhythms correctly. 


\section{Purpose and Limitations}

It is the purpose of this research project to explore how students effectively learn and perform rhythmic notation. Further, the study compares two approaches and rhythmic syllable systems used by beginning players for this notational/learning objective.

There are some limitations to the study. A qualitative research design was used due to the exploratory, descriptive nature of the project. Another researcher might have used a different design in this kind of investigation. Other limitations of this study include the small number of students who took lessons, as well as the number of lessons that were taught. The data from the four students was substantial enough to show trends in the way these particular students learn rhythm, but assumptions beyond these students' achievement would require more in-depth investigations with more students. 


\section{CHAPTER II}

\section{LITERATURE REVIEW}

Many different methods and approaches have been put forward in order to teach students to read, count, and perceive rhythms accurately. In this chapter, major approaches are outlined first, and then other studies that have compared the systems are examined. The two approaches that are used for this study are the traditional "1-e-\&-a" system, and the "Takadimi" syllable system, although there are many others that are being used in music instruction. Some approaches use numbers for counting while others instead use syllables, such as "ta, ti-ti" and "ta-ka-di-mi." Each of these approaches appears to have benefits and faults and are outlined below.

\section{Rhythmic Teaching Approaches}

Many sources offer various notational and aural rhythmic teaching approaches. The approaches are numerous. The most widely used rhythm syllable systems include the French Time-Names system, the ideas of Dalcroze, Kodály, and Orff, the "1-e-\&-a" system, the Eastman system, the Froseth system, and the "Takadimi" system. Each of these major syllabic rhythm methods is described below. 
One of the earliest known systems for rhythmic training was developed in the early nineteenth century. ${ }^{1}$ This system for counting rhythms was developed in France and was named the French Time-Names system, also called the Galin-Paris-Cheve system. In this approach, notes are counted using a French word for a duration regardless of the meter. For example, "noir" (black) is said for each quarter note, two eighth-notes are "cro-che" (eighth-note), a half-note is "bla-anch" (white), and four sixteenth notes are counted "dou-ble cro-che" (double eighth-note). Taken together, any given simple rhythm can be spoken and then performed using these patterns easily and fluidly.

\section{Adaptations to the French Time-Names System}

Toward the middle of the nineteenth century, Lowell Mason adapted the French TimeNames system for use in the United States. Instead of using the French names of the notes, he replaced these with a system that identified the value of each note within a meter and the measure. As shown in Table 1, Mason's system would count four quarter notes as "ta-ta-te-te," a group of two eighth-notes would become "ta-fa," and a group of four sixteenth notes would be chanted "te-ze-fe-ne." Whole notes are counted by holding out the syllable "ta" for four counts, and then changing the syllable to "e" for the last two counts, i.e., "ta_a_e_e_e." Two half notes are counted in the same manner, as "ta_a _ te___ _ " in order to highlight duple meter beats one and three, which are the stressed beats in this meter. In triple meter, quarter notes are counted "ta-ta-te," and six

\footnotetext{
'Edwin Gordon, Learning Sequences in Music (Chicago: GIA Publications, Inc., 1993), 265.
} 
eighth-notes are "ta-te-ta-ta-ta-te."1 Mason's system has since been updated to a simpler form and is commonly called the French Time-Names system, though it is actually a simplified American version of the original nineteenth-century system. In its simplified form, quarter notes are "ta," two eighth-notes are "ta-te," a grouping of four sixteenth notes is counted as "ta-fa-te-fe." To avoid confusion, it is referred to in Table 1 as the Current French Time-Names system.

${ }^{1}$ Gordon, 278.

${ }^{2}$ Lowell Mason, Manual of the Boston academy of music, for instruction in the elements of vocal music, on the system of Pestalozzi (Boston: J.H. Wilkins, 1836), 34-41. 


\section{Table 1}

Counting Basic Rhythms Using Varied Approaches

\begin{tabular}{|c|c|c|c|c|c|c|c|}
\hline $\begin{array}{l}\text { Note values } \rightarrow \\
\text { Rhythm system } \downarrow\end{array}$ & $d \perp d$ & $\sqrt{2}$ & 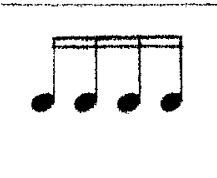 & 0 & 0 & 3 & 8 \\
\hline Galin-Paris-Cheve & noir-noir-noir-noir & cromche & dou-ble cromehe & bla-nch, bla-nch & (none indicated) & (none indicated) & (none indicated) \\
\hline $\begin{array}{c}\text { Mason-adapted } \\
\text { French Time- } \\
\text { Names }\end{array}$ & $t a+1 a-t e-t z$ & ta-fa & te-ze-fe-ne & ta a, te e & ta $a$ & ta-ta-te & ta-te-ta-ta-ta-te \\
\hline $\begin{array}{l}\text { Current French } \\
\text { Time-Names }\end{array}$ & ta-ta-lai-ta & ta-te & $t a-f a-t e-f e$ & ta $a_{\ldots}, t_{\ldots} a_{\ldots}$ & ta $a$ & ta-ta-te & ta-te-ta-ta-ta-t $t$ \\
\hline Kodaly & $t a-t a-t a-t a$ & $\mathrm{ti}-\mathrm{ti}$ & ti-ri-ti-ri & $a_{1} a_{-}, t_{\ldots} a_{2}$ & $\operatorname{tos}^{2} 00_{0}$ & tri-o-la & $t i-1 i-t i-t i-t i-t i$ \\
\hline 1-e-and-a & $1-2-3-4$ & l-and & $1-e-a n d-a$ & 1,3 & 1 & trip-o-let & $1-2-3-4-5-6$ \\
\hline McHose/Tibbs & $1-2-3-4$ & $1-10$ & $1-t a-t e+t a$ & 1,3 & 1 & |-la-lee & 1-la-lec-2-la-lee \\
\hline Froseth & $\mid-2-3-4$ & I-ne & $\mid-t a-n e-t a$ & $1,3 \ldots$ & 1 & 1-na-ni & 1-na-ni, 2-na-ni \\
\hline Gordon & $d u-d u-d u-d u$ & $d u-d e$ & $d u-t a-d e-t a$ & $d u, d u$ & du & du-ba-bi & $d u-b a-b i-d u-b a-b i$ \\
\hline Takadimi & $t a-t a-t a-t a$ & ta-di & $t a-k a-d i-m i$ & $\mathrm{ta}_{\ldots}, \mathrm{ta}_{-}$ & ta & ta-ki-da & $t a-k i-d a-t a-k i-d a$ \\
\hline
\end{tabular}




\section{The Dalcroze Approach}

At the turn of the century, Emile Jaques-Dalcroze was influencing the music world in Switzerland with an approach that he called eurhythmics, a system of teaching music using dance, movement and rhythmic training. He offered no standardized system of counting rhythms with syllables; rather, he preferred using mnemonic words. ${ }^{1}$ As an example, "run-ning" would be used for two eighth-notes in simple duple meter, and "gal-lop-ing" for three eighth-notes in compound duple meter, such as $6 / 8 .^{2}$ In Dalcrozebased rhythmic training, such words are chanted along with corresponding body movements to the pulse. In certain situations, Dalcroze educators employ the new French Time-Names System, but the use of mnemonics is more prevalent for Dalcroze-based rhythmic training.

\section{The Orff Approach}

Dalcroze was not the only pedagogue who chose to use words in order to chant a rhythm. The Orff approach, originating in Austria with Carl Orff in the 1920s, offered a related rhythm-teaching strategy. This approach also uses movement as a means of music learning, along with the aid of musical instruments such as small xylophones (commonly referred to as "Orff instruments") and recorders. By performing on instruments, children learn by doing, which is a core teaching of the Schulwerk. ${ }^{3}$ Part of

\footnotetext{
${ }^{1}$ Emile Jaques Dalcroze, Rhythm, Music, and Education, trans. Harold F. Rubenstein (London: Riverside Press, Ltd, 1967), 12-13.

${ }^{2}$ Gordon, 275.

${ }^{3}$ Brigitte Warner, Orff-Schulwerk: Applications for the Classroom (New Jersey: Prentice Hall, 1991), 8.
} 
the Orff classroom activities are based on the eurhythmics that are similar to the ideas of Dalcroze. ${ }^{1}$ Orff's Schulwerk or "School Work" offers teachers an open approach that does not mandate a fixed counting system. Different rhythm syllables and words are frequently used by teachers of the Schulwerk. In a speech given at the opening of the Orff Institute in Salzburg in 1963, Carl Orff talks about the birth of the Schulwerk:

"Schulwerk did not develop from any preconsidered plan--I could never have imagined such a far-reaching one-but it came from a need that I was able to recognize as such...Every phase of the Schulwerk will always provide stimulation for new independent growth; therefore it is never conclusive and settled, but always developing, always growing, always flowing."2

The main theme of the Schulwerk is that rhythm is learned from natural patterns in speech and the spoken language, which occur instinctually in children. Orff pedagogy, like that of Dalcroze, uses words as an aid in rhythmic chanting. Keller offers the use of bird names in Introduction to Music For Children as one example of this. Two quarter notes are "blue-bird," and four eighth-notes are "ro-bin-red-breast." 3 Orff states that he lets the children "think of words, series of words, and sentences" in order to transfer rhythm to instruments or the voice. ${ }^{4}$

\footnotetext{
${ }^{1}$ American Orff-Schulwerk Association, Guidelines For Orff-Schulwerk Training Courses (Cleveland: August Graphics, Inc., 1980), 1.

${ }^{2}$ Carl Orff, "Orff-Schulwerk: Past \& Future," in Orff Re-Echoes: Selection From the Orff Echo and the Supplements, ed. Isabel Carley (American Orff-Schulwerk Association, 1977), 3-4.

${ }^{3}$ Wilhelm Keller, Introduction to Music For Children (New York: Schott , 1974), 24.

${ }^{4}$ Carl Orff, The Schulwerk, Vol. 3 trans. Margaret Murray (New York: Schott Music Corp., 1978), 23.
} 


\section{The Kodály Approach}

Another syllable system was created around the middle of the twentieth century by Zoltan Kodály for teaching young students living in Hungary. In this method, Kodály-trained teachers begin by teaching quarter notes. All quarter notes are counted as "ta," all eighth-notes are counted as "ti," further subdivisions of an eighth-note are labeled as "ri," triplets are counted as "tri-o-la," and an eighth-quarter-eighth pattern is counted as "syn-co-pa." This is similar to Dalcroze and Orff with some obvious differences. Half notes in Kodály pedagogy are usually counted as "ta_a_" like Mason's system. However a whole note in Kodály pedagogy uses the syllable "toe." According to Choksy, the Kodály method of counting is referred to as using "rhythm-duration syllables" and is a crucial part of rhythm reading for the students of this approach. ${ }^{2}$ Teachers working with Kodály decided on using this counting system which is similar to French solfège. ${ }^{3}$ An application of this system can be found in Table 1.

\section{The "1-e-\&-a" System}

In contrast to these European-influenced traditional models, many music educators in America offer a vastly different approach to mnemonics or neutral syllable systems. While the systems described above have been used for over a hundred years, and are widely accepted in certain circles, a large number of American music educators

\footnotetext{
${ }^{1}$ Lois Choksy, The Kodály Method: Comprehensive Music Education from Infant to Adult (New Jersey: Prentice Hall, Inc., 1974), 19.

${ }^{2}$ Choksy, 23.

${ }^{3}$ Lois Choksy, The Kodály Method: Comprehensive Music Education from Infant to Adult (New Jersey: Prentice Hall, Inc., 1974), 14.
} 
use a more mathematical approach to learning rhythms. As Gordon suggests in his survey of the history of rhythmic reading, the counting system with which many instrumental music teachers are familiar today is commonly called the "1-e-and-a" system. This system evolved as a result of the rise of instrumental music in American public schools at the end of the nineteenth century. ${ }^{1}$ Whichever kind of note receives the beat as shown in the meter is counted numerically on the beat, based on its position in the measure. For example, four quarter notes in $4 / 4$ time would be counted as "1-2-3-4," and six eighth-notes in 6/8 time would be counted as "1-2-3-4-5-6." Subdivision of the beat are counted as "and," and further subdivisions are " $\mathrm{e}$ " and "a," so that four sixteenths would be counted as "1-e-and-a." Triplets are counted by using the syllables "trip-o-let." Table 1 offers examples of how this system is applied to rhythmic notation. Most musicians in instrumental settings in the United States have had this or a variant of rhythmic counting and reading at some part of their music training.

\section{The McHose/Tibbs System}

A system similar to the "1-e-\&-a" system in use today is labeled the "McHose/Tibbs system" or the "Eastman system." It was developed by Allen McHose and Ruth Tibbs of the Eastman School of Music in their Sight Singing Manual. ${ }^{2}$ In their approach, as in the "1-e-\&-a" system, each beat is given a numeral depending on the position of the beat within the measure. Eighth-notes are counted as "1-te, 2-te," and four sixteenth notes grouped together are "1-ta-te-ta." Triplets are counted as "one-la-lee," as are groups of three eighth-notes in compound duple meters, such as $6 / 8$, and compound

\footnotetext{
${ }^{1}$ Gordon, 265.

${ }^{2}$ Allen McHose and Ruth Tibbs, Sight Singing Manual (New York: F.S. Crofts \& Co., 1944).
} 
triple meters, like 9/8. If further subdivisions are made, the syllable "ta" is used. ${ }^{1}$ This system of rhythmic counting has become more popular over the past few decades among American music educators. Rhythmic examples using the Mchose/Tibbs system can be found in Table 1.

The James O. Froseth System

James Froseth adapted the McHose/Tibbs system in the 1970s into his own rhythm syllable system, which was later adapted by Edwin Gordon. Unlike the models described above, Froseth's system begins with a consideration of how rhythms fit within various metric frameworks. First, he refers to meters as duple, triple, and unusual. A meter that cannot be classified as duple or triple falls into the "unusual" category. ${ }^{2}$ An example of an unusual meter would be $5 / 8$ or $7 / 8$. Musicians using the Froseth system call eighth-notes in simple duple meter "1-ne, 2-ne" and sixteenth notes as "1-ta-ne-ta." In compound triple meter, the eighth-notes would be "1-na-ni, 2-na-ni" and sixteenths would be "1-ta-na-ta-ni-ta." In unusual meters, such as 7/8 time, the Arabic numbers are left out and replaced by syllables based on where the strong beats are placed. This is similar to the Kodály approach but is more flexible for more complex rhythmic challenges. For example, 5/8 may be counted as a group of two eighth-notes followed by a group of three eighth-notes. The syllable "du" is used for the first eighth-note of each grouping. If eighth-notes in a 5/8 measure are rhythmically grouped as a group of two followed by a group of three, they are counted as "du-be-du-ba-bi." If the eighth-notes in

\footnotetext{
${ }^{1}$ Allen McHose and Ruth Tibbs, Sight Singing Manual (New York: F.S. Crofts \& Co., 1944), 57.

2 James Froseth and Albert Blaser, Reading, Writing, and Performing Rhythm (Chicago: GIA Publications, Inc., 1982), 23.
} 
the 5/8 measure are grouped as three eighth-notes followed by two eighth-notes, the syllables are "du-ba-bi-du-be." This obviously has connections to the jazz idiom and has applications for more exotic metric structures. Examples of how rhythms are counted using the Froseth system can be found in Table 1.

\section{Edwin Gordon}

In 1993, Gordon revised the Eastman system and adapted some of Froseth's ideas to include the same syllables of the unusual meter in the duple and triple meters. While this system is often named after Edwin Gordon, James Froseth and Albert Blaser also contributed to its development. In Gordon's approach, the beat is counted as "du" and subdivided as "du-de" and further subdivided as "du-ta-de-ta." A measure full of eighthnotes in $6 / 8$ time would be counted as "du-ba-bi-du-ba-bi." Gordon describes rhythm as being divided into macrobeats and microbeats. ${ }^{2}$ Macrobeats are the beats we hear as being the longest, such as the beat you would clap along with in a song or a beat in a song you would dance to. Microbeats are shorter and are derived from the equal division of macrobeats. Gordon's rhythm syllable system can be found in the Jump Right In series for beginning band. ${ }^{3}$ Adaptations and applications of Gordon and Froseth's systems culminate in the use of the same syllables in Froseth's 1979 publication with Albert Blaser, Improvise In Popular Music Idioms. ${ }^{4}$ Both systems have seen wide use of the in

\footnotetext{
${ }^{1}$ Edwin Gordon, The Psychology of Music Teaching (New Jersey: Prentice Hall, Inc., 1971): 25.

${ }^{2}$ Edwin Gordon, Learning Sequences in Music. (Chicago: GIA Publications, Inc, 1993), 297.

${ }^{3}$ Richard Grunow, Ed Gordon, and Christopher Azzara, Jump Right In: The Instrumental Series (Chicago: GLA Publications, Inc., 1999), 54.

${ }^{4}$ James Froseth and Albert Blaser, Improvise in Popular Music Idioms (Chicago: GIA Publications, Inc., 1979), 106.
} 
the United States since their publications in the 1970s. Examples using this system are shown in Table 1.

\section{The "Takadimi" System}

Three years after Gordon published Learning Sequences in Music, another rhythm syllable system appeared. Hoffman, Pelto, and White offered the "Takadimi" system to the music education world. This is based on traditional drumming in Eastern India, particularly when playing the traditional drum, the tabla. While playing, rhythms are often accompanied by spoken syllables that correlate with each rhythm. The creators of this system consider it not a counting method like the "1-e-and-a" system and the McHose/Tibbs system, but a beat-pattern approach similar to the French Time-Names System, Gordon system, and Kodály approaches. ${ }^{1}$ The "Takadimi" system has a set of syllables for simple beat division and a set for compound beat division, but the two are related, much as in Froseth's system. The syllables are assigned to location in the beat instead of notational value. $^{2}$

In simple meter, the beat would receive the syllable "ta," then the subdivision would be "ta-di," and a further subdivision would be "ta-ka-di-mi." In compound meter, where the dotted quarter note receives the beat, the beat would still be "ta," but the subdivision of that beat becomes "ta-ki-da." The next subdivision would then become "ta-va-ki-di-da-ma." Table 1 shows some examples of rhythms counted using the "Takadimi" system.

\footnotetext{
${ }^{1}$ Richard Hoffman, William Pelto, and John W. White, "Takadimi: A Beat-Oriented System of Rhythm Pedagogy," Journal of Music Theory Pedagogy 10 (1996): 8-9.

${ }^{2}$ Hoffman, et al, 14.
} 
It is clear that there are many rhythm syllable systems for music educators to choose from, based on their teaching philosophy. Each approach is different yet accomplishes the same main goal: teaching rhythm.

\section{Comparisons and Systematic Analyses of Rhythmic Approaches}

There is a limited body of literature devoted to the systematic analysis and comparison of methods of teaching rhythm to children. The studies are scattered over several decades, and it is difficult to base a broad conclusion on the results of these studies. Few of the studies use the same strategies, and rarely has any of the research been replicated. Most of the research reaches the general conclusion that the use of syllables or related mnemonic devices is an effective pedagogical approach for teaching rhythm. The studies are surveyed below to illustrate the general trends in research and rhythm learning for beginning musicians.

In a study done by Bebeau in 1982, two groups of third-graders were given treatments using the traditional 1-e-\&-a method of counting, and what the author called a "speech cue approach." The speech cue approach used different syllables for different notes and rests, as well as corresponding visual cues. For example, a dotted half note would be counted by saying "half note dot". The visual representation would be to clap on "half," bringing hands apart on "note," and pointing to face on "dot." Both groups were given a pre- and post-test on reading rhythms correctly in $4 / 4$ time using the system 
that was taught. The results yielded no significant difference in the post-test between the two groups. ${ }^{1}$

A similar study was conducted by Palmer. In her study, groups of students were tested using either the Gordon approach or a syllabic approach related to the Kodály method as interpreted by Mary Helen Richards. Subjects were tested using a rhythm reading achievement test before and after treatment. Treatment for groups was administered over a five-month period for the Gordon experimental group, the Richards experimental group, and a control group. The control group did not receive a special rhythm instructional program. Palmer found no significant difference between the groups, stating that the analysis "revealed no statistically significant difference between the Richards and Gordon approaches."2

In a study of perceptions of counting systems, Brittin surveyed students at an honors band clinic in order to gather information about which counting systems the students had used throughout their education. After the initial survey, students were given exercises to complete on finding incorrect measures and rhythms. Part of the results revealed that most students surveyed (69\%) used the traditional "1-e-\&-a" system of counting, while $18 \%$ reported using ta's and titi's. After scoring the musical exercises for this study, Brittin concluded that "the counting system used in the band programs had no significant effect on certain rhythmic skills."33

\footnotetext{
${ }^{1}$ Muriel Bebeau, "Effects of Traditional and Simplified Methods of Rhythm-Reading Instruction," Journal of Research in Music Education 30, no. 2 (1982): 116.

${ }^{2}$ Mary Palmer, "Relative Effectiveness of Two Approaches to Rhythm Reading for Fourth-Grade Students," Journal of Research in Music Education 24, no. 3 (1976): 117.

${ }^{3}$ Ruth V. Brittin, "Middle School Instrumentalists' Perceptions of Counting Systems," Bullitin of the Council For Research in Music Edcuation 148 (Spring 2001): 16.
} 
A study by Colley compared alternative methods of teaching rhythm. ${ }^{1}$ In her study, second and third graders were divided into four groups: a control group, a group which used Kodály syllables, a group which used Gordon syllables, and a group which used words for counting, such as "Washington" and "Mississippi." The four groups were pre-tested and post-tested on recognition, dictation, and performance. No significant differences were found between groups.

The most significant finding was that the group most comparable to Orff's language-based approach scored best in the performance post-test. The other groups scored about the same and had no significant difference. It is interesting to note, however, that Colley observed that the subjects using the Orff language-based approach had the longest attention spans and the Kodály group had the shortest. In addition, she found that the Gordon group performed the examples with a consistent feel of pulse, while the language-based approach was the most effective for improving the subject's dictation and performance skills. Both the Kodály and Gordon groups had problems remembering the correct syllables. ${ }^{2}$

In 1987, Patricia Shehan conducted a study to investigate the "development of music literacy, as well as to contribute to knowledge in the related areas of memory and mnemonics."3 She compared the effects of four presentation modes on the rhythmic performance of second graders and sixth graders. The four modes of presentation were audio-rhythm, audio-mnemonics, audio-visual, and audio-visual-mnemonics. As in

\footnotetext{
${ }^{1}$ Bernadette Colley, "A Comparison of Syllabic Methods for Improving Rhythm Literacy," Journal of Research in Music Education 35, no. 4 (1987): 221-235.

${ }^{2}$ Colley, 232-234.

${ }^{3}$ Patricia Shehan, "Effects of Rote Versus Note Presentations on Rhythm Learning and Retention," Journal of Research in Music Education 35, no. 2 (1987): 120.
} 
Bebeau's study, the rhythms Shehan used were all notated in $4 / 4$ meter. In the audiorhythm mode, rhythms were presented on a woodblock. The audio-mnemonics mode used syllables based on the teaching of Japanese theater drums, so the syllables were unfamiliar to the subjects. While the rhythm was being performed on a woodblock in the audio-visual mode, the subjects were shown a card with the notation pictured. In the audio-visual-mnemonics mode, the notation was shown while the theater drum syllables were used to perform the rhythm. The subjects were required to memorize and perform each of the presented rhythms on a woodblock.

Shehan observed that regardless of what presentation mode was used, "older students consistently learned the patterns twice as quickly as the younger children."1 She also found that "the use of mnemonics in the aural and visual modes reduced the number of attempts necessary for an accurate performance, although not significantly so." ${ }^{2}$ In the conclusion of the study, however, Shehan found no significant differences between the groups.

A quantitative study was conducted by Terrence Bacon in 1998 to determine if the use of the "1-e-\&-a" system of counting rhythms, the Gordon rhythm syllables, or no syllables results in significantly different student achievement. In his study, student achievement was defined in terms of meter recognition and performance of duple and triple meter in varied musical examples. ${ }^{3}$ Three groups of middle-school band students were divided into three groups and a different syllable system was used with each group over twelve weeks of instruction. After this time, the subjects were given a meter

\footnotetext{
${ }^{1}$ Shehan, 124.

${ }^{2}$ Ibid.

${ }^{3}$ Terrence Bacon, "A Comparison of Rhythm Syllable Systems Used in Beginning Instrumental Instruction" (Unpublished master's thesis, Michigan State University, 1991), 25-26.
} 
recognition test, and the subjects' performances of four musical exercises were rated by two judges using a rating scale.

The results of his study showed that subjects taught using either Gordon's syllables or no syllable system performed significantly better than those using the "1-e\&-a" system in triple meter. However, Bacon did note that subjects did not have the opportunity to perform music in triple meter as part of the regular classroom instruction. He states that, "Because triple meter was less familiar to the students, aptitude may have played a larger role in the triple meter performances than the duple meter performances" and that "The use of more songs in triple meter may have changed the results." No other significant differences were found.

\section{Conclusion}

In conclusion, it appears that, while many counting systems were used in the above studies, they yielded few to no significant difference in as far as the final results. This research suggests that any of these approaches will produce the same result.

\footnotetext{
${ }^{1}$ Bacon, 49.
} 


\section{CHAPTER III}

\section{METHOD AND DESIGN}

\section{Introduction}

The purpose of the present study was to compare two commonly-used rhythmic syllable systems, the " $1-\mathrm{e}-\&-\mathrm{a}$ " system and the "Takadimi" system, in order to determine the efficacy of each when teaching beginning music students in a public school setting. The expected outcome was to discover if there are trends in how middle-school students perceive and reproduce rhythms. It was surmised that this information would give both the researcher and the band director a better understanding of the two rhythm learning approaches and that it would prove particularly valuable for those music educators who struggle to find worthwhile rhythm pedagogy for beginning instrumentalists.

The study explores the two approaches and observes how students perceive and learn rhythm using the two different systems. In this study, students' experience of various rhythm syllable systems is examined in a qualitative design. The questions that guided this research are:

1. In what ways do students first approach a rhythm they do not know?

2. How do students perceive a rhythm based on how it is written?

3. What problems do students encounter when trying to count a rhythm?

4. In what aspects do students find success in counting rhythms accurately?

5. What differences are found (if any) between the two rhythm syllable systems according to the above questions? 
This chapter outlines the design of the study, as well as how the research was implemented and how data was collected.

\section{Design}

A qualitative design was chosen for this study. The value of face-to-face interactions with the subjects as well as the central questions and purpose of this investigation appeared appropriate to better understand how students learn rhythm. A qualitative design seemed to be the most appropriate for this topic and the personality of the researcher. ${ }^{1}$ Permission from the University of Louisville Human Subjects Protection Program Office (HSPPO) was granted well in advance of the research.

Four band students were selected from the sixth-grade band from a middle school in Oldham County, Kentucky. A small sample was preferred due to the qualitative design of the study. The four students were selected from band class because they were already familiar with traditional music notation such as quarter notes and eighth-notes and exhibited a desire and motivation to progress on their instruments. Sixth-grade students were preferred because that is when students in this district begin band. At this point, therefore, they would not be accustomed to a particular system of counting rhythms. In this way, the results of the study would not be misrepresented because a student might be more accustomed to a particular syllable system that was used in that band program rather than the syllables used in the study.

It was also essential that the students show proficiency playing either percussion or woodwind instruments. The researcher, a band director herself, determined that brass

\footnotetext{
${ }^{1}$ Corrine Glesne, Becoming Qualitative Researchers: An Introduction (New York: Longman, 1999), 6.
} 
players would be excluded from the sampling pool because in the early stage of learning, pitch rather than rhythmic accuracy is the main challenge for brass students, and this could interfere with the results of the study. Woodwind players appeared to be a better choice for this investigation of rhythm learning because of the limited technical problems that were not so pronounced for beginning brass students.

\section{Selection of Subjects}

The four students that were selected to participate met with the researcher along with their parents/guardians the month before any research began. A face-to-face meeting was necessary in order to ensure that parents and students understood all aspects of consenting to participate in the study. The researcher explained the study to parents and students in the form of a consent document as well as verbal explanation from the researcher. Participants were told that student participation would have no effect on their grade in band class.

It was explained that there were no foreseeable risks to the study. Parents were told that benefits from participation would include additional instrumental practice for their child, gaining the experience of having music lessons, and possibly bettering the child's rhythmic reading accuracy. Once questions were answered and all participants felt comfortable with the design and intent of the project, parents signed a consent form, and students signed an assent form agreeing to participate in the study and to be videotaped as part of the study. Each parent received a copy of both forms and was encouraged to contact the researcher with any questions at anytime before, during, or after the study. After consent was granted and student assent obtained, the researcher 
contacted each child about lesson times. Each student met with the researcher for a half an hour a week for approximately five weeks of music lessons.

Randomization was not possible with this project; however, students were selected based on their abilities, gender, and age. Because of the qualitative nature of the study, randomization was not central for collecting data and reporting findings. The band director was asked to identify four students of an average level of rhythmic reading accuracy who are able to stay after school and receive music lessons. Two alto saxophonists and two clarinetists were chosen, two male and two female. Each student was given private lessons on his or her instrument by the researcher, and one of two rhythm syllable systems was used for each of two groups of students (see Table 2).

\section{Table 2}

Scheduled Differences Between the Four Students

\begin{tabular}{|c|c|c|c|}
\hline & Gender & Instrument & Syllable System \\
\hline Student A & Female & Clarinet & Takadimi \\
\hline Student B & Male & Alto Saxophone & Takadimi \\
\hline Student C & Female & Alto Saxophone & le\&a \\
\hline Student D & Male & Clarinet & le\&a \\
\hline
\end{tabular}

Two of the students had music lessons using the "1-e-\&-a" system of counting. The other two students used the "Takadimi" system in the lessons. The lessons lasted for a half hour and took place every week over a five week period (see Table 3). 
Table 3

Schedule of Lessons

\begin{tabular}{|c|c|c|}
\hline & Wednesdays & Thursdays \\
\hline Student A & & $3: 45-4: 15$ \\
\hline Student B & $3: 45-4: 15$ & \\
\hline Student C & & $4: 15-4: 45$ \\
\hline Student D & & $4: 45-5: 15$ \\
\hline
\end{tabular}




\section{Data Collection}

Field Observations

Lessons with each student were videotaped and the lessons were transcribed in order to gather all information that may have been missed during the lesson. The researcher kept a reflective journal in order to capture observations immediately after each lesson. This was also done in order to better understand and reflect on student learning. Rich, detailed description was utilized in the field journal in order to probe the situations and circumstances surrounding the actions and performance of each student. This added to information gained from the video recorded lessons concerning how the students progressed over the five weeks of lessons. This method of gathering information is appropriate as described in accepted, recognized guidelines for qualitative research. ${ }^{1}$

\section{Student Interviews}

After the five weeks of lessons, interviews with the students took place, which were also recorded. Students were asked the following specific questions at the exit interview. The interviews were then transcribed from the tape-recordings.

1. In what way do you feel the system used during lessons helped you understand rhythms?

2. Tell me about any problems you encountered or any ways in which the system may have hindered you from learning the rhythms.

3. Tell me how you feel about your experience with this system. In what ways did it make you feel more or less confident about playing new rhythms?

4. How is this system different than any system you learned previously?

\footnotetext{
${ }^{1}$ Corrine Glesne, Becoming Qualitative Researchers: An Introduction (New York: Longman, 1999), 29.
} 


\section{Data Analysis}

Videotaped lessons were viewed and analyzed to ascertain how and why errors were made by each student. After transcribing each lesson, the researcher reviewed the different kinds of mistakes each student made. From this process, the mistakes could be codified under different categories, as suggested for qualitative research by Glesne. ${ }^{1}$ In this way, data collected can be organized into meaningful categories that are applicable to the purpose of the research. Data collected from the videotape transcripts reflected that students made mistakes that fell into six categories: (1)holding a note or rest too long, (2)playing a note or rest too short, (3)wrong syllable used, (4)unsteady pulse, (5)stops and hesitations due to rushing, and (6)incorrect rhythm due to other reason. These were shortened into the abbreviations $\mathrm{H}, \mathrm{P}, \mathrm{W}, \mathrm{U}, \mathrm{S}$, and I, respectively. Formal theory was employed in the analysis of the data in order to make connections between the phenomena of using rhythm syllable systems to performing with rhythmic accuracy. Formal theory, broader than empirical generalizations, is used to explain a whole class of phenomena. In this way, commonalities and differences among each student's performance were gleaned.

\section{Procedures}

Table 3 outlines the teaching schedule for the four students in this study. With two of the four participants, the researcher used the "Takadimi" system in counting rhythms; she used the "1-e-\&-a" system with the other two students. This was taught by demonstration by the researcher; it was then imitated by the student, who counted the

\footnotetext{
${ }^{1}$ Corrine Glesne, Becoming Qualitative Researchers: An Introduction (New York: Longman, 1999), 29.
} 
selected rhythmic patterns out loud while clapping. This was done to demonstrate mastery of each pattern presented throughout the lesson. Patterns presented for each lesson are outlined in Appendix A. Pedagogically appropriate guided questions were asked during lessons to lead the student to rhythmic accuracy. Video recording was utilized in order to chronicle the interactions between student and teacher during each lesson over the five week period.

\section{Materials Used in the Lessons}

During the five-week study, the individual students each had identical materials to draw from. The Premier Performance Band Method Book One ${ }^{1}$ was used during study as it favors no particular counting system. Due to the open-ended options afforded by such a book, the researcher was able to employ either of the two chosen rhythm systems without confusing the student. The exercises were broken down into basic rhythm patterns that were learned in each one, and this can be found in Appendix A. As a supplement to the book, a sheet of rhythmic exercises created by the researcher was also used. This exercise sheet can be found in Appendix B.

Certain exercises were planned for each lesson, drawing from the book as well as from the exercise sheet. The students had covered whole, half, quarter, and eighth-notes in band class since the beginning of the year, and they had recently covered ties and dotted-quarter and eighth-note combinations in $2 / 4,3 / 4$, and $4 / 4$ time. Each student was given a diagram of a rhythm tree and corresponding syllables that should be used for notes using the specified syllable system. These can be found in Appendix C. The

\footnotetext{
${ }^{1}$ Ed Sueta, Premier Performance: An Innovative and Comprehensive Band Method (Rockaway, New Jersey: Ed Sueta Music Publications, Inc., 1999).
} 
exercises used in lessons were mostly focused on quarter- and eighth-note patterns in different time signatures, as well as dotted-quarter and eighth-note combinations. The Premier Performance book has 127 melodic exercises; the lessons in this study encompassed exercises 102-107. During the five-week span of the instrumental lessons, students completed the exercises in their book in band class. The researcher generally did not introduce students to exercises they had not played in class, but rather reviewed the ones they played in class. In this way, students had fewer problems with pitches, but still had room to improve rhythmically. 


\section{CHAPTER IV}

\section{RESULTS}

\section{Daily Logs}

The researcher kept a $\log$ for reflection during the study. Each day's log offered some interesting findings. Students at first were very shy about playing in front of another person, especially with the video camera. In the first lessons with each of the four students, that it was noted how often they needed to be encouraged to play out, that it was acceptable to make mistakes. The researcher encouraged confidence by clapping the rhythm along with the student or counting out loud with them. At different times throughout the first few lessons, students were in the habit of stopping as soon as they made a mistake instead of finishing the exercise. Whenever possible, they were encouraged to play through mistakes. Students began to do this on their own toward the last few lessons.

Students who were introduced to the "Takadimi" syllable system (students A and B) were both excited about the new way of counting and were eager to learn. It was surprising to note how quickly the two students learned to count using "Takadimi" syllables with quarter and eighth-notes. Sometimes Student A would confuse the syllables "ta" and "di" while counting rhythms, but the spoken rhythm that came out was usually correct. Students $\mathrm{C}$ and $\mathrm{D}$ had no trouble with the 1e\&a system and seemed to show a little more confidence in counting and playing than Students A and B. 
The second week of lessons, Student A seemed to be very hesitant about playing as was not nearly as confident as the week before. While her "Takadimi" syllables were better, the tempo would fluctuate when she counted and her pitches and rhythms were not as consistent. When her mistakes were gently corrected, she seemed unhappy. The researcher decided to ask her about her day after the lesson was over. She stated she was supposed to be in the school talent show, but the other students who were supposed to perform with her decided to give up on it. This reminded the researcher that children, like adults, have good days and bad days. This student's mood could have affected her attention span and motivation level for that lesson.

During the third week of lessons, more eighth-note patterns were explored as well as dotted half notes. Something interesting was found that was not intended to be a factor in this study: the beaming of notes. On the fourth line of the sheet of student exercises, the sixth measure has four eighth-notes all beamed together followed by two quarter notes (see Appendix B). Each one of the four students made the same counting mistake on this measure, counting it as "1-e-\&-a" or "Takadimi" instead of " $1 \& 2 \&$ " or "taditadi." Student A was the only student who figured it out before being told by the researcher. The other three students were convinced that since the four notes were beamed together, they were sixteenth notes. After teaching them about beaming, the researcher decided to make a note to revisit the matter in subsequent lessons to make sure they really got it. The next week they did remember, after some hesitation.

As lessons progressed, the researcher noted that students were equally proficient while playing and counting using either syllable system. For example, when counting a pattern consisting of an eighth-note followed by an eighth-rest, student B counted this in 
the fourth lesson as "di" instead of "ta." Student C encountered this rhythm in the fifth lesson and counted it as "\&" instead of " 1. " In the daily log from lesson four with Student B, the researcher wrote:

"At first, he wanted to count "eighth, eighth-rest, eighth, eighth-rest" as "di, di," but after thinking about it, got it right, seeing they fall on the beat. Sometimes I think kids want to count a note by what kind of note it $\underline{i s}$, not by what kind of note precedes it like they should."

It was first projected that by the last few lessons, Students A and B would want to get back to how they first learned to count in band class, using the "1-e-\&-a" syllables. However, it seemed that they were still eager to use the syllables and had learned to count rhythms proficiently using this system.

\section{Common Themes}

Overall, students from both groups achieved the same skills in rhythmic accuracy throughout the study, regardless of syllable system. Both pairs of students showed progress in proficiently counting rhythms as the lessons progressed. In the first few lessons, both pairs of students struggled with syllable placement during counting until they became comfortable with counting out loud. For example, Student A would sometimes count two eighth-notes as "di, ta" instead of "ta, di." Students C and D would sometimes count "\&, 1 " instead of " $1, \&$." Although rhythmically they were correct, the students were using incorrect syllables.

Using the daily logs and the transcriptions from the lesson videos, the researcher was able to observe how students misinterpreted a rhythmic passage. It became easier to 
observe this by creating a coding system for rhythmic mistakes, as described in Chapter Three. The researcher first read through the video transcriptions and marked all times when students did not play or count a rhythm accurately. Generally, students would hold a note or rest too long, play a note or rest too short, use the wrong syllable in counting the note within a rhythm, have an unsteady feeling of pulse, hesitate frequently within the passage, or play an incorrect rhythm. From this observation, categories were created for mistakes and each mistake was classified into one of the categories. The categories and abbreviations were: student held note or rest too long $(\mathrm{H})$, played note or rest too short (P), used the wrong syllable in counting (W), kept an unsteady pulse during performance (U), made stops and hesitations due to rushing (S), or played an incorrect rhythm for any other reason (I). A tally sheet was used in order to track the kinds of mistakes the students made and to better observe commonalities and differences. The tally marks have been changed into numbers to facilitate comparison. These results are shown in Table 4 .

\section{Table 4}

Mistakes Made by Students During Five Weeks of Lessons

\begin{tabular}{|c|c|c|c|c|}
\hline & $\begin{array}{c}\text { Student A } \\
\text { (female, clarinet) } \\
\text { Takadimi }\end{array}$ & $\begin{array}{c}\text { Student B } \\
\text { (male, alto sax.) } \\
\text { Takadimi }\end{array}$ & $\begin{array}{c}\text { Student C } \\
\text { (female, alto sax.) } \\
1 \text {-e-\&-a }\end{array}$ & $\begin{array}{c}\text { Student D } \\
\text { (male, clarinet) } \\
\text { 1-e-\&-a }\end{array}$ \\
\hline $\mathbf{H}$ & $\mathbf{8}$ & 12 & 6 & 6 \\
\hline $\mathbf{P}$ & 13 & 10 & 8 & 6 \\
\hline $\mathbf{W}$ & 10 & 5 & 11 & 18 \\
\hline $\mathbf{U}$ & 6 & 5 & 5 & 7 \\
\hline $\mathbf{S}$ & 3 & 9 & 9 & 10 \\
\hline I & 4 & $\mathbf{8}$ & 4 & 10 \\
\hline Total & $\mathbf{4 4}$ & $\mathbf{4 9}$ & $\mathbf{4 3}$ & $\mathbf{5 7}$ \\
\hline
\end{tabular}


Observations suggested that of the mistakes that were made, playing a note for the incorrect duration and using the wrong syllables were the most frequent mistakes among the four students. Overall, the observations suggested that students using the "Takadimi" system of counting seemed more proficient in playing without hesitations and counting using correct syllables in lessons. The students who used the "1-e-\&-a" system were less likely than the "Takadimi" students to play a note longer or shorter than it was written. There was no significant difference between the performances of all four students. All students displayed some trouble in keeping a steady pulse while counting out loud or playing.

\section{Unusual Observations and Comments}

After reading through researcher logs and transcribing the videotaped lessons, some surprising tendencies surfaced. Perhaps the most unexpected observation dealt with the frequency and type of mistake made by the students. Student A tended to play notes and rests shorter than the written value, while Student B held notes for longer than the value. Both of these students used the "takadimi" system.

In contrast, Students $\mathrm{C}$ and $\mathrm{D}$, who both used the " $1-\mathrm{e}-\&-\mathrm{a}$ " system, both made the most mistakes by using the wrong syllables to count. This was an unexpected outcome because students used the " $1-\mathrm{e}-\&-\mathrm{a}$ " system in band class, so they were already somewhat familiar with it. Student $\mathrm{C}$ seemed to make the most rhythmic mistakes by using the wrong syllables when counting out loud. In spite of this difficulty remembering syllable names, student $\mathrm{C}$ seldom played rhythms incorrectly by lengthening or 
shortening the value of the written note. This is in contrast with the performance of Students A and B, who used the "takadimi" system.

The number of stops and hesitations while playing was similar among all of the students, except for Student A, who rarely stopped in the middle of an exercise. This behavior is rare for a beginning band student. However, Student A had played violin since an early age and perhaps this attributed to the few hesitations in her lesson performance.

\section{Final Interview and Questions}

At the conclusion students were asked the four questions described in Chapter Three. Responses are summarized below in terms of common themes.

\section{Question 1}

The first question of the exit interviews was, "In what way do you feel that the system used during lessons helped you understand rhythms?" Student A stated that "Takadimi kind of helped because it's not as easy as 1, 2, 3, 4 but not as hard as some other counting systems." When asked if she thought the "Takadimi" syllables seemed harder to learn than the "1-e-\&-a" system, she stated that it was. In contrast, Student B responded that it didn't matter to him that the beats weren't numbered. He continued that even though each beat was "ta," he still knew where he was in the measure.

Students C and D, who both used the "1-e-\&-a" system, were consistent with each other when they both stated that it was easier to play a rhythm after counting it. Specifically, Student D said, "It helps me to know when to play and when to rest, and to 
help me know what beat I'm on." This theme seemed to surface in lessons over and over again. Among all four students, they all performed better when they counted the rhythm first, no matter what system they were using.

\section{Question 2}

Question two of the exit interview asks, "Tell me about any problems you encountered or any ways in which the system may have hindered you from learning the rhythms." Students A and B replied that they didn't find any problems with it, and both stated that it was just "different." Student B elaborated that the "Takadimi" syllables seemed a little easier to learn and facilitated his counting.

Students $\mathrm{C}$ and $\mathrm{D}$ both stated that they had no problems with the "1-e-\&-a" system of counting itself, but student $\mathrm{C}$ added that the faster notes (sixteenth notes) were harder to count and play. All of the students learned their respective syllable systems by the second or third lesson.

\section{Question 3}

The third question at the end of the lesson period was "Tell me how you feel about your experience with this system. In what ways did it make you feel more or less confident about playing new rhythms?" Student A, who learned with "Takadimi" syllables, responded, "I think I know a little bit more about counting, and it was kind of cool. The syllables weren't hard to say. Just when I'm saying them with one of these exercises, but learning the syllables wasn't hard." Student B, who also worked with the 
"Takadimi" system commented, "I felt about the same as when I use "1-e-\&-a." It was fun to learn the system, I had fun with it."

Student C felt different working with "1-e-\&-a" syllables. She said, "Sometimes it's hard to remember what the counts are called, and sometimes it's hard to remember what beat I'm on." Student D commented similarly, "Some of the "1-e-\&-a's" are different to use and get used to."

\section{Question 4}

The final question to students was, "How is this system different from any system you learned previously?" Student A felt that it was different because in the system she used in band class ("1-e-\&-a" system), she counted the numbers in order, but in the new system there is no order of the beats. She added that the numbers from the "1-e-\&-a" system seem to help a little bit more in knowing where she was within a measure. Even though Student B also used the "Takadimi" system in lessons, he felt differently. He stated that both systems were about the same difficulty, even though "Takadimi" was "harder to learn at first." He stated, "The '1-e-\&-a's are hard to remember, but this makes it a little bit simpler. They're about the same to say."

Student $C$ had never used a different system and said she liked the "1-e-\&-a" system. Student D had elementary school experience with the Kodály approach of counting rhythms using the syllables "ta" and "ti, ti." He stated that the $6^{\text {th }}$ grade band used those syllables a little bit at the beginning of the year and then related it to the "1-e\&-a" system. He went on to say, interestingly, "Using ' $1-e-\&$-a's is easier for playing 
instruments. 'Ta's' and 'ti, ti's' are good for singing in choirs." When asked why he believed this to be true, he shrugged and said he didn't know. 


\section{CHAPTER V \\ DISCUSSION}

Generally, the goal of this project was to determine how students responded and achieved using two rhythm syllable systems. It is clear that students learned how to subdivide beats using both systems. The students caught on quickly to the new idea of using different syllables. Each group did just as well as the other in counting and playing the rhythms using the two different syllable systems. There was no apparent difference in performance between the two systems, the clarinet players versus the saxophone players, or the males versus the females. It is evident, however, that students performed rhythms most accurately after they first counted them. This was true among all four students no matter what counting system was taught.

\section{Limitations of the Study}

There were several limitations of this study. The biggest limitation was only studying four students. This was intentional as a qualitative study, but also limits any generalizations beyond these four students. Time constraints also affected the depth and interpretive power of the findings discovered in this five-week project. Many times there were conflicts due to other music lessons, sports practice, after school rehearsals, and other activities the students were involved in. When this occurred, make-up lessons were scheduled according to each student and the researcher. 
Another issue of consideration was that students had some experience with the "1-e-\&-a" system of counting. By choosing beginning instrumentalists, it was hoped that students were still in the introductory stages of learning this system. The purpose of this was so the study would not be biased toward the " $1-e-\&-a$ " system since students were not very familiar with it. It is possible since they had been learning simple rhythms using this counting system for a few months prior to the study that they may have been slightly biased toward the "1-e-\&-a" system. For similar future studies, researchers might want to use beginning instrumentalists in the first month of instruction so that they have had little to no experience with any counting system in the band curriculum.

Other limitations to consider were the use of only woodwind players. No brass, percussion, or string players were used, and this may have limited results. It would be interesting to see if the instruments had a relationship with their learning of each system.

Another limitation is that students were chosen from only one school district. Perhaps a different pool of students would result in different findings.

\section{Areas for Further Consideration}

Due to the limitations of the study in terms of time and student sampling, there are areas suggested for future research to advance the observations made in this study. A study of different band programs that use different rhythm syllable systems would be beneficial. Instead of focusing on one student, band rehearsals from different schools could be videotaped. In this situation, band directors and students could be interviewed about their experience with the counting system. A study of this type could deepen one's 
understanding of how various systems are implemented in the band setting instead of a lesson setting.

Using assessments in sightreading for a large ensemble of students using only one syllable system for counting is another area that could be explored. Results may be different if students are playing in an ensemble setting in which they are reading a piece they have never seen before. In such a larger group setting, it may be possible that students would hesitate less frequently during performance because they are not playing alone. Likewise, it is probable that they would keep a steady pulse playing in an ensemble in front of a conductor. Both of these factors might yield more accurate rhythmic reading from students.

As noted in the study's limitations, it would be valuable to study with more subjects and, a different sampling of wind and percussion players. Brass players and percussionists might show another aspect of this study that did not arise with woodwind players. Another study could also approach rhythm syllable systems in the choral classroom, or observe how older students deal with new syllables systems.

As always, different method books could be used, and a comparison between counting systems among band methods could be discussed. More information could be gathered if students could meet more often and there were more time for the study. Perhaps if the researcher were able to hold the lessons during school hours it would be feasible to expand the study in this way.

Another area of further study would be to replicate this design using different rhythm syllable systems. While the two used showed limited difference in learning, other systems might yield contrasting results. 
Finally, a longitudinal study following a single case over an extended period of time might yield additional information about rhythm learning and performance. In this way, the researcher could focus on the learning patterns of one student and use different strategies for learning rhythm. This sort of study could also include a pre-test and a posttest to measure student proficiency in rhythmic reading and performance. These kinds of data-gathering tools could have also been used in this study if time allowed, and can be used in any study relating to rhythmic learning.

\section{Final Reflection}

The information gleaned from this study can be valuable to music educators looking for ideas to increase student efficiency in reading rhythms. Since it is mandated by the Kentucky Department of Education through the Core Content for Arts and Humanities ${ }^{1}$ that students need to learn how to read music, it is important that music teachers find varied approaches to teaching rhythm, a core element of music, in order to better reach each student.

Teachers can feel free to teach their students specific syllable systems to fit the needs of each individual. This kind of approach works best if working with students oneon-one in a private lesson environment. However, in the researcher's opinion guided by the results of this study, it is best in an ensemble setting to choose one rhythm syllable system and use it consistently with those students. Young students seem to feel more comfortable counting and performing with a syllable system that they know. There is no syllable system that is a "fix-all" for rhythmic mistakes of young players. It is suggested

\footnotetext{
${ }^{1}$ Kentucky Department of Education, Core Content for Arts and Humanities Assessment, (August 2006)
} 
that the band director research some of the different systems and find one he or she is comfortable using in the classroom.

Music educators reading this study are encouraged to try new approaches with their students and take note of the results. It is hoped that all music educators will continue to grow as educators by finding new and different ways to bring music closer to students. This will foster a love for music in students that will help them to be successful not only in their musical endeavors, but also in other things they choose to follow in life. The motivation for this study came from a desire to help students be more successful in playing rhythms in music. The researcher believes that this project has helped to do that more effectively. 


\section{REFERENCES}

American Orff-Schulwerk Association. Guidelines For Orff-Schulwerk Training Courses. Cleveland: August Graphics, Inc., 1980.

Bacon, Terrence. "A Comparison of Rhythm Syllable Systems Used in Beginning Instrumental Instruction." Unpublished master's thesis, Michigan State University, 1991.

Bebeau, J. "Effects of Traditional and Simplified Methods of Rhythm-Reading Instruction." Journal of Research in Music Education 30, 2 (1982): 107-119.

Bloom, Benjamin. Taxonomy of Educational Objectives: the Classification of Educational Goals. New York: Longman, 1984.

Brittin, Ruth V. "Middle School Instrumentalists' Perceptions of Counting Systems." Bulletin of the Council For Research in Music Education 148 (Spring 2001): 1218.

Choksy, Lois. The Kodály Method: Comprehensive Music Education from Infant to Adult, $2^{\text {nd }}$ ed. New Jersey: Prentice Hall Inc., 1974.

Colley, Bernadette. "A Comparison of Syllabic Methods for Improving Rhythm Literacy." Journal of Research in Music Education 35 (Winter 1987): 221-235.

Conway, Colleen. "Good Rhythm and Intonation from Day One in Beginning Instrumental Music." Music Educators Journal 89 (May 2003): 26-31.

Froseth, James and Albert Blaser. Reading, Writing, and Performing Rhythm. Chicago: GIA Publications, Inc., 1982.

Publications Inc., 1979. . Improvise in Popular Music Idioms. Chicago: GIA

Glesne, Corrine. Becoming Qualitative Researchers: An Introduction. New York: Longman, 1999.

Gordon, Edwin. Learning Sequences in Music. Chicago: GIA Publications, Inc, 1993. . The Psychology of Music Teaching. New Jersey: Prentice-Hall Inc., 1971. 
Grunow, Richard, Ed Gordon, and Christopher Azzara. Jump Right In: The Instrumental Series. Chicago, GIA Publications, Inc., 1999.

Hoffman, Richard, William Pelto, and John W. White. "Takadimi: A Beat-Oriented System of Rhythm Pedagogy." Journal of Music Theory Pedagogy 10 (1996): 730.

Jaques-Dalcroze, Emile. Rhythm, Music, and Education. Translated by Harold F. Rubenstein. London: Riverside Press, Ltd., 1967.

Keller, Wilhelm. Introduction to Music For Children. New York: Schott, 1974.

Kentucky Department of Education. Core Content for Arts and Humanities Assessment. August 2006.

London, Justin. "A Psychological Addendum to Takadimi: A Beat-Oriented System of Rhythm Pedagogy." Journal of Music Theory Pedagogy 10 (1996): 31-36.

Mason, Lowell. Manual of the Boston Academy of Music, for Instruction in the Elements of Vocal Music, on the System of Pestalozzi. Boston: J.H. Wilkins, 1836.

McHose, Allen and Ruth Tibbs. Sight Singing Manual. New York: F.S. Crofts \& Co., 1944.

Music Educators National Conference. The School Music Program: A New Vision. The K-12 National Standards, Pre-K standards, and what they mean to music educators. Reston, VA: MENC, 1994.

Orff, Carl. The Schulwerk, Vol. 3. Translated by Margaret Murray. New York: Schott Music Corp., 1978.

. "Orff-Schulwerk: Past \& Future" in Orff Re-Echoes: Selection From the Orff Echo and the Supplements. ed. Isabel Carley. American Orff-Schulwerk Association, 1977.

Palmer, Mary. "Relative Effectiveness of Two Approaches to Rhythm Reading for Fourth-Grade Students." Journal of Research in Music Education 24, 3 (1976): $110-118$.

Price, Harry E.; Blanton, Frank; et al. "Effects of Two Instructional Methods on High School Band Students' Sight-Reading Proficiency, Music Performance, and Attitude." Update 17 (Fall/Winter 1998): 14-20.

Schleuter, Stanley. A Sound Approach to Teaching Instrumentalists, $2^{\text {nd }}$ ed. New York: Schirmer Books, 1997.

Shehan, Patricia. "Effects of Rote Versus Note Presentations on Rhythm Learning and Retention," Journal of Research in Music Education 35, no. 2 (1987): 117-126.. 
Sueta, Ed. Premier Performance: An Innovative and Comprehensive Band Method. Rockaway, New Jersey: Ed Sueta Music Publications, Inc., 1999.

Warner, Brigitte. Orff-Schulwerk: Applications for the Classroom. New Jersey: Prentice Hall, 1991. 
APPENDLX A

RHYTHMIC PATTERNS USED FOR STUDENT LESSONS 


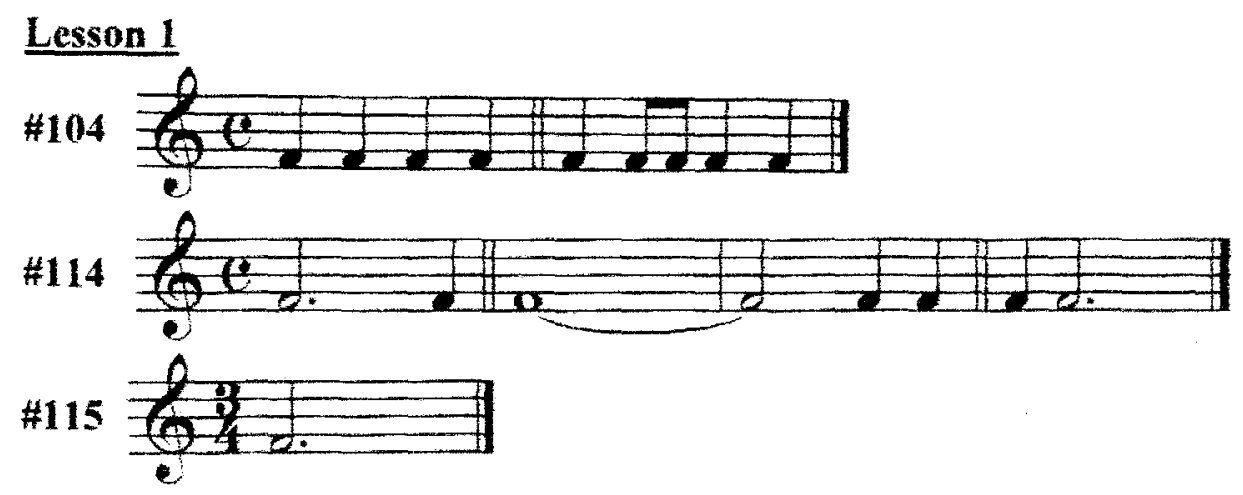

Lesson 2

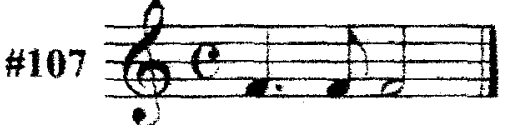

$\# 110$

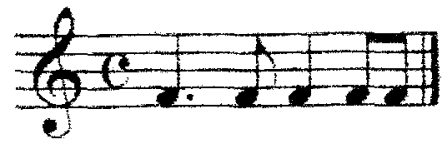

Exercise $1 \frac{2}{30+2}$

Exercise $2 \frac{0}{(6 x+2)+2}$

Exercise $4 \frac{2}{7 t^{2}+2+1}$

Exercise $5 \frac{0}{(\operatorname{mat}+21+1}$

Lesson 3

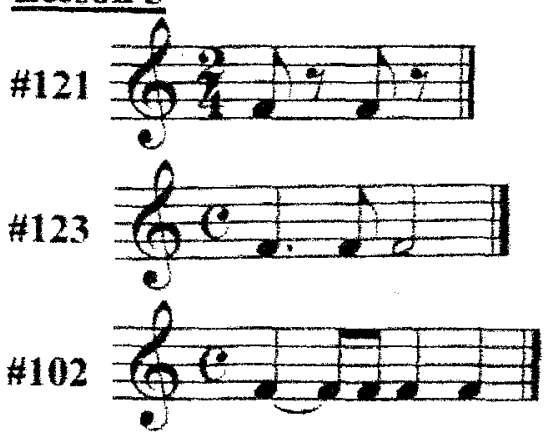

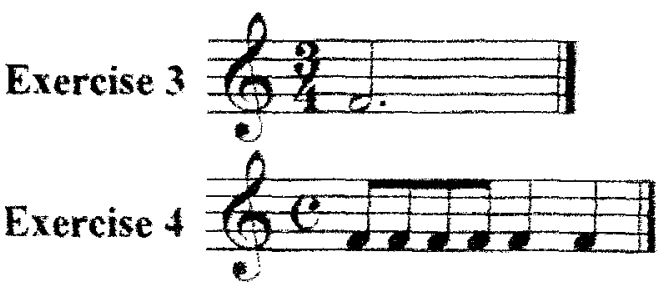




\section{Lesson 4}

$\# 105$

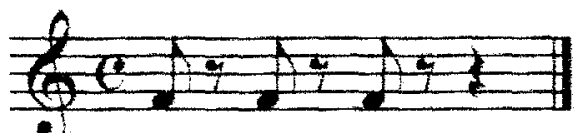

\#124

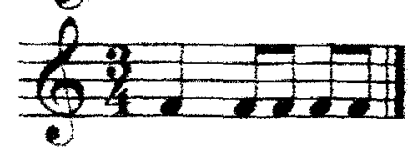

Exercise $2 \frac{0}{2}$

Exercise $4 \operatorname{lot}^{(t+2 x+1}$

Exercise $6 \frac{2 x+1-7}{9+2}$

Exercise $7 \frac{0}{2} c+2+2+2+1$

Lesson 5

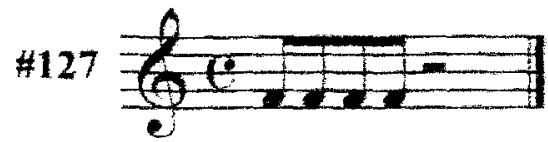

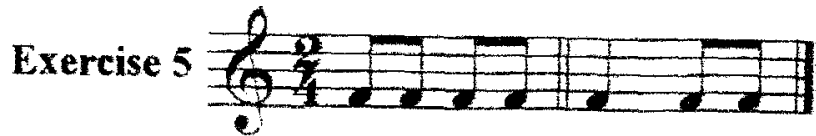

Rhythm Exercise 9 te

Rhythm Exercise 13 a

Rhythm Exercise 20

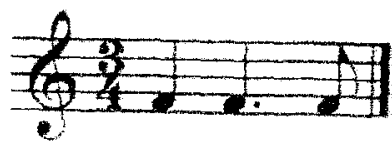


APPENDIX B

SUPPLEMENTAL RESEARCHER-CREATED EXERCISE SHEET 


\section{Clarinet Exercises}

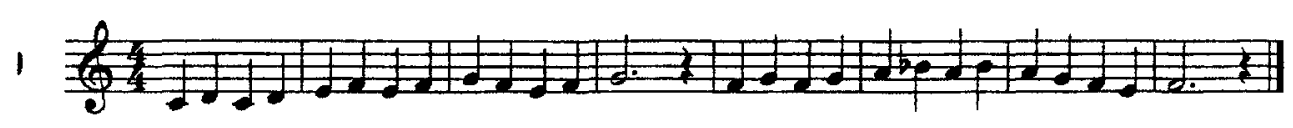

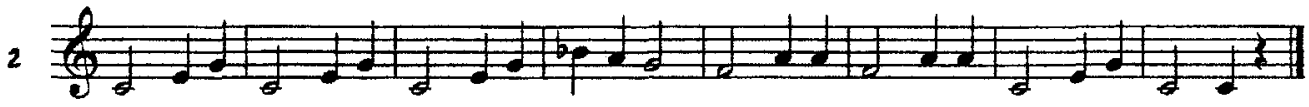

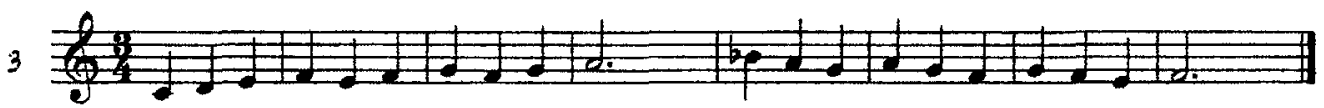

4 प4

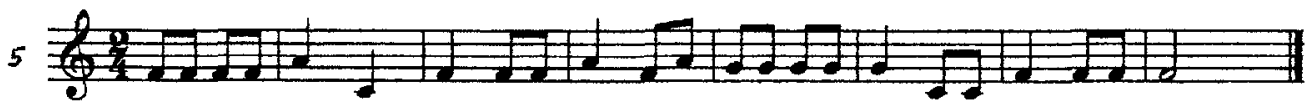

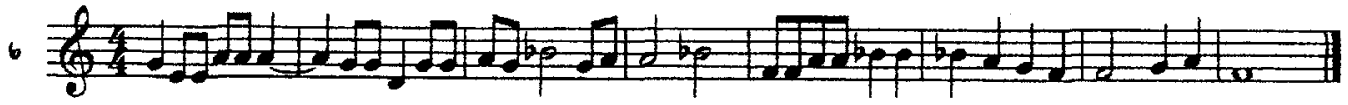

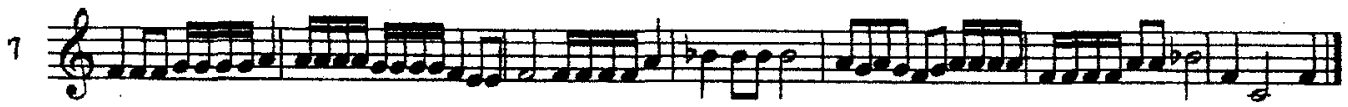


APPENDIX C

RHYTHM TREE AND SYLLABLES FOR EACH SYSTEM 


\section{Takadimi Rhythm chart}

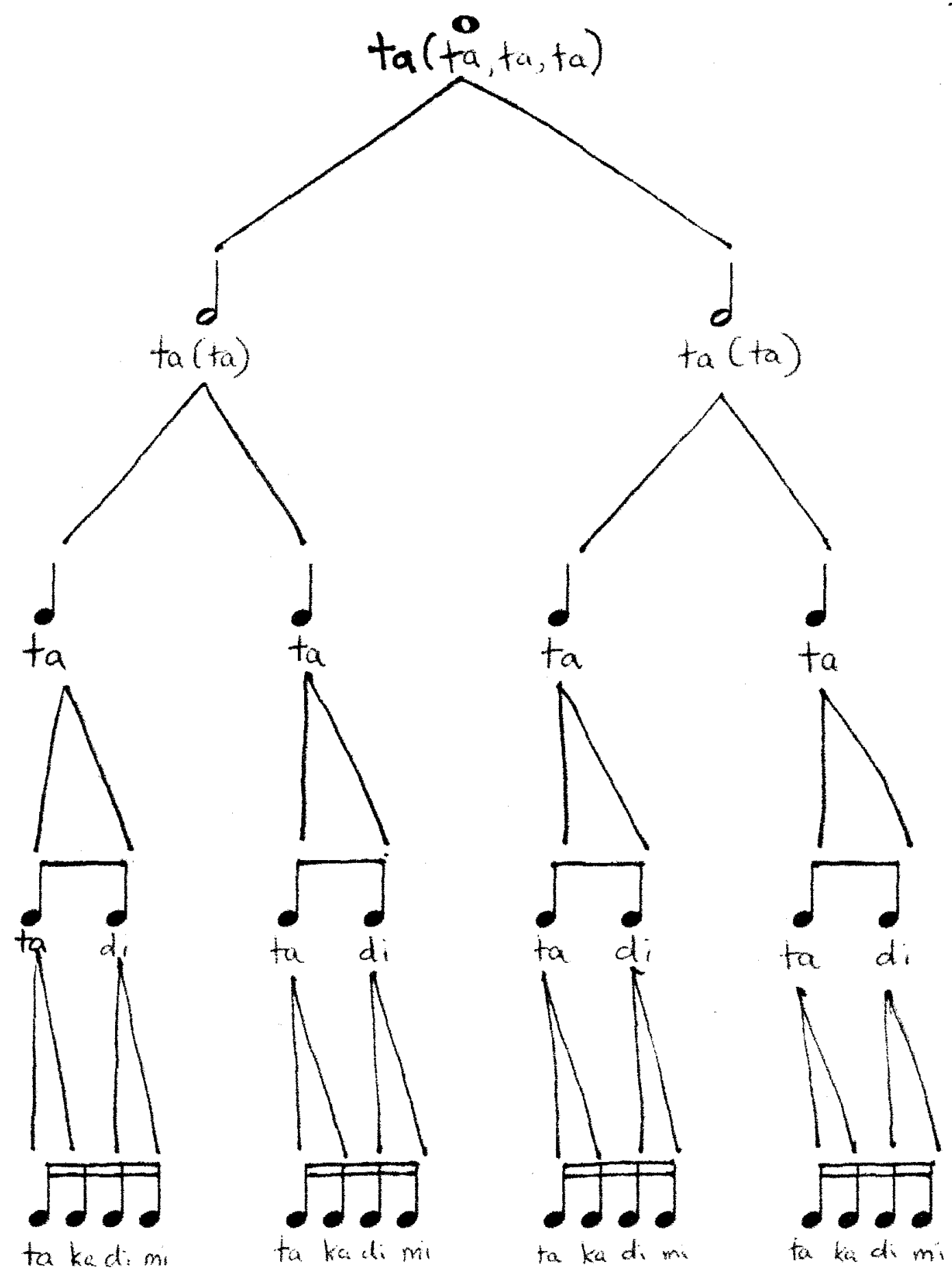


1e\&a Rhythm chart

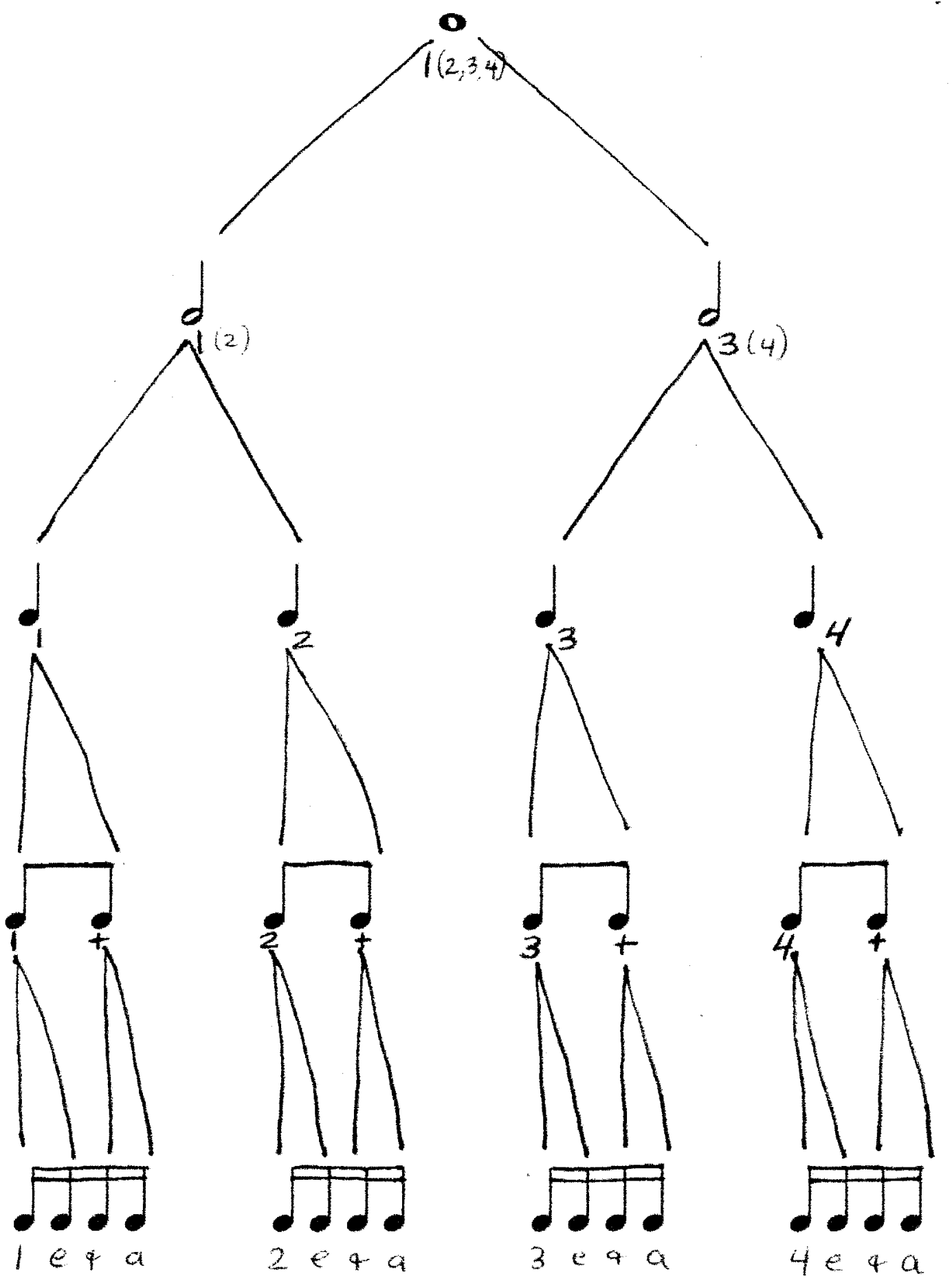




\section{CURRICULUM VITAE}

\section{Tammy R. Fust}

100 H Creekside Place

LaGrange, KY 40031

Phone (502) 222-8169 E-mail: tocamarimba@bellsouth.net

\section{Education}

B. M. in Music Education, University of Kentucky, 2001

\section{Teaching Experience}

Shelby County East Middle School, Shelbyville, KY

- Grade 5-8 Instrumental Music Teacher (2003-present)

- Worked with students in $5^{\text {th }}-8^{\text {th }}$ grade and was involved in KMEA events such as Spring Concert Festival, Solo \& Ensemble Festival, and $5^{\text {th }}$ District Band.

Organized concerts, regularly communicated goals to parents, began a pep-band to play at student basketball games, spent time after school working with students to reach their goals.

Percussion Instructor, various schools in Kentucky (July 2003-present)

- Work primarily with students at Oldham County High School, including rehearsals for percussion ensembles, teaching lessons, writing marching percussion music, and teaching drill during the marching season. Have worked with 6th grade percussionists at Oldham County Middle on improving skills on a weekly basis. Have also worked with South Oldham High School and Owen County High School during band camp and post-camp rehearsals.

Private Lessons Teacher in Percussion, Self-Employed (September 1996 to present)

- Taught students ranging between the ages of 10 and 17

- Assisted students in reaching their goals on the instrument

Substitute Teacher, Oldham County Schools (August 2002-August 2003)

- Gained skills working with all ages in many settings. Was able to substitute for instrumental music and have productive rehearsals.

Music Teacher, Bath County Schools, Owingsville, KY (August 2001-June 2002)

- Taught general music at two elementary schools in Bath County: Bethel Elementary and Salt Lick Elementary Schools. Completed KTIP program.

Student Teaching, Tates Creek Middle School, Lexington, KY (Spring 2001)

- Taught instrumental music (6th-8th grade band) 
- Collaborated with teacher to prepare for concerts and district band. Also conducted sectionals with brass and woodwind groups, all grades.

\section{Private Study}

- Studied percussion under James Campbell, University of Kentucky (1997-2001)

- Studied percussion under Mark Tate of the Louisville Orchestra (1993-1997)

\section{Professional Affiliations}

- Kentucky Music Educators Association (KMEA)

- Music Educators National Conference (MENC)

- Percussive Arts Society (PAS)

- Women Band Directors International (WBDI)

- National Band Association (NBA) 